Ethical Norms,

Particular Cases 
ALSO BY JAMES D. WALLACE:

Moral Relevance and Moral Conflict Virtues and Vices 


\section{Ethical Norms,}

Particular Cases

JAMES D. WALLACE

Cornell University Press

ITHACA AND LONDON 
Copyright $(1996$ by Cornell University

All rights reserved. Except for brief quotations in a review, this book, or parts thereof, must not be reproduced in any form without permission in writing from the publisher. For information, address Cornell University Press, Sage House, 512 East State Street, Ithaca, New York 14850.

First published 1996 by Cornell University Press.

Library of Congress Cataloging-in-Publication Data

Wallace, James D., 1937-

Ethical norms, particular cases

James D. Wallace.

p. $\mathrm{cm}$.

Includes bibliographical references and index.

ISBN o-8014-3213-8 (cloth : alk. paper)

1. Ethics. 2. Practice (Philosophy) 3. Authority. I. Title. BJ1031.W29 1996

$171^{\prime} .2-\mathrm{dc} 20$

96-5043

Printed in the United States of America

$\Leftrightarrow$ The paper in this book meets the minimum requirements of the American National Standard for Information SciencesPermanence of Paper for Printed Library Materials, ANSI Z39.48-1984. 
To My Mother and Father

Jane P. Wallace

Donald F. Wallace 
This page intentionally left blank 